\title{
Can Management Control Systems be applied in SME? A case study of small manufacturing in Indonesia
}

\author{
MARKO HERMAWAN \\ JESSICA TRIANA PUTRI \\ Universitas Bina Nusantara
}

\begin{abstract}
Management control systems (MCS) consists of general measures human capital and performance management that provide an appropriate guideline to improve a company's performance and management control, and budgeting issues. In conducting the research, deep understanding in management control system theory, Chinese and Javanese values in doing business, and characteristics of small-medium family business is highly essential. The paper analyzes the extent to which MCS enables to identify performance, as well as human resource issues, in conjunction with management control in a small manufacturing company. In a particular setting such as Indonesia, other components, such as cultural context, collectivism, leadership, and ethnic group, contribute into an essential factor in MCS. An enterprise such as PT. GAA illustrates various issues as a small manufacturing business, that closely related to family business and cultural dimensions. It is believed that even a generic MCS has little implication towards its performance improvement. However, most of the literature that scrutinize Indonesian SME found that the socio-economic milieu influence more than the procedural systems designed by the theory.
\end{abstract}

Keywords: management control systems, ethnography, small business; performance

Intisari: Sistem pengendalian manajemen (SPM) terdiri dari ukuran umum modal manusia dan manajemen kinerja yang memberikan pedoman yang tepat untuk meningkatkan kinerja perusahaan dan kontrol manajemen, dan masalah penganggaran. Dalam melakukan penelitian ini, pemahaman yang mendalam dalam teori sistem pengendalian manajemen, nilai-nilai Cina dan Jawa dalam melakukan bisnis, dan karakteristik usaha keluarga kecil menengah sangat penting. Paper ini menganalisis sejauh mana SPM memungkinkan untuk mengidentifikasi kinerja, serta masalah sumber daya manusia, dalam hubungannya dengan pengendalian manajemen di sebuah perusahaan manufaktur kecil. Dalam pengaturan tertentu seperti Indonesia, komponen lain, seperti konteks budaya, kolektivisme, kepemimpinan, dan kelompok etnis, berkontribusi menjadi faktor penting dalam SPM. Perusahaan seperti PT. GAA menggambarkan berbagai masalah sebagai bisnis manufaktur kecil, yang terkait erat dengan dimensi bisnis dan budaya keluarga. Dipercaya bahwa bahkan SPM generik memiliki sedikit implikasi terhadap peningkatan kinerjanya. Namun, sebagian besar literatur yang meneliti UKM 
Indonesia menemukan bahwa lingkungan sosio-ekonomi mempengaruhi lebih dari sistem prosedural yang dirancang oleh teori

Kata kunci: management control systems, ethnography, usaha kecil, peningkatan kinerja

\section{Introduction}

Current studies on Management Control Systems (MCS) and Indonesian business has focused on leadership (Efferin, Frisko, \& Hartanto, 2016; Efferin \& Hartono, 2015), business development (Berry, Rodriguez, \& Sandee, 2001; Tambunan, 2005), gender issues (Anggadwita, Luturlean, Ramadani, \& Ratten, 2017; Efferin et al., 2016) and cultural context (Efferin \& Hartono, 2015; Efferin \& Hopper, 2007). There is, however, an essential aspect in observing the implementation of small-medium enterprise (SME) and manufacturing industry, which is less appreciated. Such a setting requires a thorough understanding of a small set of organizational culture that eventually complements to its management control. This paper incorporates three significant areas as the research elements; family business, MCS, and organizational culture. It might be difficult to find the relevance, however, as Tsamenyi, Noormansyah, and Uddin (2008) might argue, that cultural background influences organizational culture, and can be useful to explain management control in less developed countries' family business.

Several problems emerge from unsuitable MCS that is implemented in small enterprises, with limited human resource and administration. Moreover, the familyowned business organizational culture is commonly influenced by the owner background culture and later will affecting the managerial control system (Efferin \& Hopper, 2007). Therefore, this case study attempts to analyze the interplay between MCS, organizational culture, and SMEs; and produce a research question of: "How does MCS intertwine with the organizational culture of an SME?"

The purpose of this study is to identify a gap between theoretical perspectives and practical situation, in this case, a small enterprise in Indonesia. The setting is a newly developed family business, which operates in a manufacturing business. In conducting the research, deep understanding in management control system theory, Chinese and 
Javanese values in doing business, and characteristics of small-medium family business is highly essential. In assessing the phenomena, the paper utilizes MCS frameworks to build strong problem preposition and solution presentation. While trying to understand such obstacles, the paper attempts to identify findings that could produce a different result from the current research on the same field; generating new insights for the particular parties that could be benefited from this research.

\section{Theoretical Framework}

\subsection{Issues in SME and family business}

The term family business is built by combining the word family and business, which implies that the purpose of the establishment is to provide positive outcomes for both family and business. In other words, the family business aims to promote the wellbeing of both parties (Berghe \& Carchon, 2003; Sorenson, 2000). However, research has shown that both seem to be in a very different direction, success in one will disrupt the other; therefore, it is suggested for either party to adapt (Sorenson, 2000). For example, many family businesses have chosen to involve other family members in the business merely because of family relationship or trustworthiness. They were recruited regardless of their qualification, which later will jeopardize the future of the business by their inadequate performance. García Pérez de Lema and Duréndez (2007) argue that recruitment issue appears in SME and family business. This is shown by the lack of emphasis on personal training and in management qualification. The commitment to provide training for employees, regarding activity and expenditure, is shallow in the family firm. This example is a common and quite crucial issue in family business. In the end, based on several experts, it is proven that parallel welfare of both parties is impossible (Sorenson, 2000).

Moreover, they found that family business has its characteristics of management style in which the enterprise tends to give less priority on planning and monitoring. High degree of informality and less supervision are some of the issues, that result in less professionalism. Formal form of management controls are rarely implemented in the family business; even though it exists, in practice it becomes inferior to social and 
cultural control. Evidence from the previous research on family-owned university shows that formal accounting exists only to satisfy the Education Ministry's requirements (Tsamenyi et al., 2008).

García Pérez de Lema and Duréndez (2007) also confirmed that family business would be less productive when being supervised by family members in comparison to external professionals. Due to a higher degree of informality, the relationships between members are become more personal and intimate, where employees in a family business are not accustomed to being strict with another worker. As the consequences, it becomes less useful for an internal manager to monitor the subordinates. Thus, they proposed to involve external professional managers to control the business, to add value to the company itself.

After discussing the issues attached to the family business, this section will present the theoretical identification of the business itself, which includes the differentiation and uniqueness of the family business. Theoretically, in its classification, a company could be defined as a family business through several approaches, which justify the existence of family control over the business (Senftlechner \& Hiebl, 2015). The first approach is from the ownership structure, which figured when a person or family holds a specific percentage of shares, usually from $20 \%$ to $50 \%$. The second approach is from the management formation, which appeared when one or more family members possess dominant ownership and have power in controlling the daily management (Efferin \& Hartono, 2015; Herath, Herath, \& Azeez, 2006). Consequentially, through controlling function, the management will unintentionally transfer its core values to non-family employees. Thus, the leader's values are considered the source of organizational culture, and those values will create integration among organizational members (Efferin \& Hartono, 2015).

Family business could be seen as different from non-family business. There are lots of distinguishing characteristics between both parties (Senftlechner \& Hiebl, 2015). Most of the time, the size of the company is the distinguishing factor of a family business; however, it is not necessary, there are also big companies that are still considered as a family business. Taking Wall-Mart Stores as an example, it is the largest 
retail store in the USA. Nonetheless, it yet being ruled by the Walton family (Herath et al., 2006).

There are also several other assumptions that are juxtaposing family owned business and non-family owned business. First, the strategic decision might contain the long-term survivability than non-family owned business does, by making decisions that affect not only the current but also one or more succeeding generations to come. Second, it is generally accepted that, other than financial goals, family-owned business emphasized more on non-financial goals; keeping the business alive in the hand of the family, for instance (Sharma, 2004). Third, family business characterized by a lower degree of formality, especially in their early years, due to a high level of trust between family members (Senftlechner \& Hiebl, 2015).

\subsection{Management Control Systems and SMEs}

There are issues associated with the utility of MCS to SMEs. Some of these related to the degree to which MCS concept is applied, and its relationship between theoretical and empirical research (Malmi \& Brown, 2008). They suggest a proper implementation to MCS typology that can suit the needs of managers, enable to impact individuals for better decision and able to achieve organization goals (Chenhall, 2003). Management control systems (MCS) is best studied as a package, which combines control systems with the environment where the control system will be implemented. There are several reasons behind the statement; first, MCS does not work in isolation. Second, studying the MCS alone will influence the conclusion drawn from a study. Third, the study will lose its meaning; while MCS purpose is to design a system to produce desired outcomes (Malmi \& Brown, 2008). Thus, studying MCS as a package has many good reasons. Therefore, this research combines MCS with a family business. Studies confirm the connectivity between family business and management control. Management is a system within a particular environment used by management to align employee's behavior with organizational objectives and to manage internal interdependencies (Efferin \& Hopper, 2007). It is thus an integral part of a company, and it could help a 
firm to achieve its intended goals and objectives when appropriately implemented (Herath et al., 2006).

On the other hand, MCS could be problematic when an improper implementation is placed; and caused by three reasons (Malmi \& Brown, 2008). First, Lack of direction; it is the situation where the employees are unaware of the employer expectation. Thus, it is the function of management control in informing and directing the employees on actions they need to undertake in their contribution to the fulfillment of organizational objectives. Second, a motivational problem from employees that result from personal interest at the expense of the organization's one. And the last cause is a particular limitation, which appears when the employees do not have the capabilities to do the job.

Merchant's model of MCS (Merchant \& Van der Stede, 2007) consists of three controls that could be implemented to strengthen the control environment in a particular organization. The first is the resulting control, which controls the behavior of employees through the decision and action they took. Implementing this type of control is highly effective when the desired results are well defined, the employee is accountable for the result, and the output is measurable (Efferin \& Hopper, 2007). To implement result control, organizations must go through four steps, which are defining performance dimensions, measuring performance, setting performance targets, and providing rewards (Merchant \& Van der Stede, 2007). The central question needs to be asked in determining performance dimensions is "what are the dimensions that important in achieving the desired outcome?"

Moreover, as challenging as defining the performance dimensions, it is equally critical to choose the performance measures that are congruent with the selected performance dimensions. According to Efferin and Pontjoharyo (2006), the Chinese are concerned with selecting and recruiting staff, in which cultural values, knowledge, and skills essential. The performance measure will inform the employees on what is critical to be done thoroughly. In Indonesia's case, such a performance management system is influenced by culture, society and powerful actors (Mutmainah, Prabowo, \& Raharja, 2010). 
Based on Redding (1993) this type of control is considered appropriate to be implemented in countries such as Hongkong and Indonesian, where the 'culture' is effective in inducing creativity to achieve the targeted outcomes since there are no limitations on what action should be taken to reach the predefined set of targets. Moreover, due to the excessive utility of Guanxi (trust-based networking), companies in these countries tend to neglect management procedures such as less standardized displays, little usage of marketing catalogs, no sales policy, and less distribution organization (Efferin \& Pontjoharyo, 2006).

The second is action controls emphasize more on the employees' means or behavior, rather than on the final result (Merchant \& Van der Stede, 2007). By definition, action control is the activity of ensuring that employees perform specific action known to be beneficial to the organization and preventing employees from performing a harmful action. The purpose of this control is to promote obedience and direct employee behavior towards a set of desired responses (Efferin \& Hartono, 2015; Malmi \& Brown, 2008). This control put the employee under liability and accountable for their behavior.

Lastly, personnel controls, focus on employee's assurance to perform tasks satisfactorily. In other words, personnel control helps employees to understand the organization's expectations of them. There are ways to implement a good personnel control, which are through selection and placement, training, and job design and resourcing (Merchant \& Van der Stede, 2007). On the other hand, cultural controls serve to promote a healthy and positive organizational culture, facilitating all members in the business or organization to monitor each other and to have self-awareness in doing their best for their organization (Efferin \& Hartono, 2015; Efferin \& Hopper, 2007). Therefore, culture is a control used to regulate the behavior of the member (Malmi \& Brown, 2008). This paper promotes the aspect of cultural restrictions. This control is implemented through mutual monitoring and might be highly effective in a collectivist culture, similar to Indonesia. In collectivist countries, people tend to avoid anything that could humiliate themselves, since they are aware that people are watching. Cultural controls are implemented to strengthen the organizational culture of a company, which 
through codes of conduct, group rewards, intra-organizational transfers, physical and social arrangements, and tone at the top. Previous studies by Efferin and Hartono (2015), Tsamenyi et al. (2008) and Lukiyanto (2016) confirm that the role cultural context of collectivism, kinship, and harmony, influence the controlling aspect of an organization. It is imperative to observe the impact of such elements to align with the local setting of the organization, in particular, Indonesia.

\subsection{The Chinese Value of Guanxi and Trustworthiness}

Guanxi is a word that defines complex social networking that has been passed through generations as the Chinese culture. It indirectly binds people in mutual obligation, assurance, trust, and understanding. Moreover, it governs Chinese attitudes toward long-term and social business relationships (Hwang, Golemon, Chen, Wang, \& Hung, 2009). According to Efferin and Pontjoharyo (2006), Chinese Indonesia comprises of two categories: the totok (genuine traditional Chinese practice) and jiaosen (a mixture of Western, local and Chinese/Confucian tradition). The practice of Guanxi in the society is more related to a broad range of everyday life relationship that is more informal and less hierarchical, which are following the principals of reciprocity. Moreover, the word guanxi implies several characteristics. The first characteristic depicts the relationship between two parties, which are situational and informal, and is built on the discretion of the parties involved (Lewis, 2006). Second, once the relationship is established, the principles of reciprocity will follow, which means that a favor given by one party will be returned by the other (Lin \& Ho, 2010). Third, the principles of reciprocity work on the personal trust (Wijaya, 2008), which will continue to grow as the act of reciprocity is realized. Fourth, people will display their belief to the other through the action of grouping (Efferin \& Hopper, 2007). Efferin and Pontjoharyo (2006) argue that the Chinese Indonesian Guanxi is formed through a formal socio-cultural association based on their surnames or places of origin in China. Fifth, guanxi relationships are mostly long-lasting and stable or at least expected to be lengthy. Sixth, to last, the established relationship needs to be grown. Seventh, guanxi has various degrees of relationship strength and stability, from low to high. Eighth, in 
establishing guanxi, a person could choose its relationship partners freely; it cannot be forced to establish guanxi with everyone. From the characteristics mentioned above, it could be concluded that trustworthiness grows since the very start the relationship begin (Efferin \& Hartono, 2015; Efferin \& Pontjoharyo, 2006).

\section{Research Method}

This study is contingency-based research that occupies an ethnographic study, which focuses on the people as the source of study. The authors gathered evidence from a study on management control system in a manufacturing company owned by a Chinese Indonesian, through observation and a semi-structured interview. The intention to employ ethnographic approach is to study the shared pattern of behavior, language, and actions of a sample group in its natural setting (Creswell, 2014), in this case, Indonesian business culture. An etic and emic approach is combined to retrieve information from the actor's thoughts and actions in their self-understanding (Morris, Leung, Ames, \& Lickel, 1999; Smith, 2011), while interpret the study using the outsider perspective using prevailing theory. By nature, the study emphasizes more on insiders or participant's interpretation of the phenomenon as part of their world (Efferin \& Hopper, 2007), and cultural anthropologist translates it to the strive to understand the culture from native's perspective (Morris et al., 1999).

The data collection processes used two phases. The first phase was conducted to understand the prevailing condition of the organization. There were four respondents; the owner, the manager, the administrator, and the owner's wife. In this phase, the researcher asked general questions to the respondent. Those questions mainly concerning the job description of the stakeholders, the working environment, job satisfaction level, and experience during tasks. Through this phase, the researcher aimed to establish a sense of trust between the interviewer and the interviewee; thus, the second phase's conversation could be executed more conveniently. The questions asked in phase two were mainly related to the most frequent issues revealed by the respondent in phase one, particularly issues in management control system. At this phase, the researcher attempted to dig deeper into the problems, and an additional type of questions 
was asked. The principal participants were the owner, the manager, and the administrator.

While conducting the second phase, the authors began to execute the observation method. Based on preliminary observation. The road to the manufacturing facility was very steep, yet bumpy and rough. A local source said that the road had been repaired not long ago. However, due to lots of trucks and heavy car passing, the road has not lasted for a long time. And yet, it has not been repaired ever since. There is a small kiosk standing in the facility areas owned by a local resident. Showing her gratitude, the kiosk owner likes to give the company owner some offering (such as raw peanuts and bananas) every time the owner comes to the facility. The office building is relatively small. Inside there are one medium size living room, two office rooms, one bathroom/toilet, and one small kitchen. Those office rooms used to be bedrooms and the office was located in the living room. The manager used to do the paper works from his house in Jakarta, but now he stays in the office building longer; therefore the office rooms need to be made.

\subsection{PT. GAA Profile}

The business started in 2012 as a calcium manufacturing company. The owner, Mr. $\mathrm{H}$, invited his niece, Mr. Y, and his nephew, Ms. M, to invest in the establishment of the factory, with the ownership percentage of $70 \%, 15 \%$, and $15 \%$ respectively. Later, Mr. $\mathrm{H}$ assigns Mr. $\mathrm{Y}$ to hold the management control and to oversee the factory in Padalarang, while Mr. H only controls the business from Jakarta. Every weekend, mostly on Sunday, Mr. H and Mr. Y meet in Mr. H's house to discuss the progress of the business.

Meanwhile, Ms. M only plays the role of a minority shareholder of the company and joins the meeting once in a while. The business also employs non-family members, which majority are locals. These employees are assigned to be the factory workers and office helper. Therefore, no other than the shareholders play the role of management.

This section explains the profile of the selected research site, which includes the history, environment of the manufacturing company, and the competition with more prominent manufacturers in the same industry. 
The establishment of this manufacturing company was encouraged by the need for more product supply. The founder of this company, Mr. H, was initially a sole limestone powder trader, who bought the powder from suppliers and sold it to business users. However, in the following year, the supplying partners could not fulfill the product demand. Therefore, Mr. H decided to establish a manufacturing company of his own in the limestone mountains area, Padalarang, West Java. These are expressed in his statement:

"Because at that time, when I was making the trade, many supplying partners could not be able to provide as what was needed " (Mr. H, male).

Later at that time, Mr. $\mathrm{H}$ decided to buy the piece of land for the manufacturing facility. However, he could not be able to control the company by himself, due to a considerable distance of the location and his residency in Jakarta. Therefore, he offered his nephew, $\mathrm{Mr}$. Y, to be the manager of the controlling duty. Other than that, $\mathrm{Mr}$. $\mathrm{H}$ also asked $\mathrm{Mr}$. $\mathrm{Y}$ and his other niece, Ms. M, to contribute monetarily as shareholders of the company. After all, parties have agreed to the terms, this company was established.

Operating as a manufacturing company that produces ground limestone, PT. GAA has its competitors. The company size of the competitors varies. One thing that makes competition hard for PT. GAA is that more significant competitors usually have their limestone mountain to be mined. As a result, they have cheaper cost to obtain the raw material in comparison with other smaller manufacturing company, such as PT. GAA. Besides, currently, there was a problem associated with the mining license. Every miner has to have the permit to dig the mountain, or else it will be marked as an illegal miner. Until now, there is only one miner who possesses that license. This situation reduces the bargaining power of a manufacturer since that only miner holds full control over the supplies of raw materials.

\subsection{Findings}

The finding suggests five phenomena based on the critical issues raised by the owner and the stakeholders. Mr. H has opened his business with the intention to expand the business. Projected to earn a higher return, the primary goal of the founder is to 
achieve monetary profit as targeted. Based on the initial interview, it was found that the manager also holds the same purpose. Additionally, the owner also wished to pass the ownership to his children in the future. After knowing the projections and aims of the company and to further narrow the research, the Authors also figured the problematic situation in the year the research was conducted. Also from the interview with the stakeholder, the Authors understands that all of the monetary target (e.g., productions target and sales target) have been achieved aggregately; although there are several underachieved months, the other overachieved months could be covered for it. Since the monetary profit is very much significant in this family business, the Authors scoped this research by focusing more on finding problems attached to this area, especially the causes for the underperformed months.

\subsubsection{Phenomenon 1: Unsatisfactory employees}

The first discussed phenomenon was the problem with employees. Through the interview, the owner and the manager have spoken their feelings of their current employees. The following is the answer from the owner asked about his opinion with his current employees.

I would say that I am quite satisfied with my employees, but I am expecting more. The mechanic currently tends to be negligent in the machinery maintenance, and I hope they could pay more attention to it, so it would not be broken. Moreover, the monthly financial reports are also overdue, and I am quite disappointed since it makes me unable to watch over my company on time (Mr. H, male, 59).

The owner complained about the lack of quality from his employees. Those complaints include things that are viewed as crucial for the owner. With the owner vision to profit from the business, it is clear that the lacking qualities of the employees could hamper the process of profit making itself. However, the owner seemed to accept his employees as it is; it was shown through his expression and tone during the interview. There is no urgency to hire new employees from the owner. It was a contradicting notion from the 
owner; however, the explanation of the owner's expression will be discussed in the next section, as a different phenomenon arises.

On the other hand, the manager's response to quality issues differs from the owner's perspective.

It is usual stuff; employees are expecting more from us but delivering deficiencies in their services. For example, they asked for more compensation from us, although not explicitly. But in return, their capabilities in doing the job are sometimes insufficient; resulting in, for example, the machinery breakage (Mr. Y, male).

The manager is the person who regularly presents in the manufacturing facility. Therefore, his perspective might be different from the owner. While the owner sees things from the helicopter point of view, the manager might have a horizontal angle, in which he regularly faces the employees and the problem attached to them.

In the above interview, the Authors could understand that both the owner and the manager are not satisfied enough with the performance of the current employees. Both parties indicate their disappointment in their statement. The current employees are seen as negligent and slow in processing the document, which leads to machinery breakage and overdue reports.

\subsubsection{Phenomenon 2: Remoteness of the manufacturing facility location}

The second phenomenon relates to the extent to which manufacturing location is of the concern. Based on the author's observation, the condition in the office building is quite weak. The wall cracks and this might be due to the heavy work going on in the factory attached just at the back of the office building. The bathroom/toilet here is quite clean for emergency use, but the utilities are not in their best condition. The ambiance is pleasant in the office building, very much different from the manufacturing facility. The air circulation in the office building is quite lovely, with windows facing to the forepart and a firmly locked back door connected to the factory. However, in the factory, when operated, all is covered in white with the small particle of the ground limestone (CaCo3). All of the workers in this company are men. It could be seen that the 
relationship between all workers in this facility is so healthy and warm. Most of the time they put their smile on their faces, lower their head every time they meet the manager or the researcher. They tell jokes and chat while placing the stone in the machine.

However, during their break, at noon, usually most of the labors, whose house is nearby, go to their own homes to have lunch with their family. The factory itself is divided into two, outdoor and indoor. Inside the facility, there are the types of machinery, which grind the limestone into a small grain. During work hour, people barely come in. Most labor work from the outside, they put the stone into the mouth of the machine, which located on the border between indoor and outdoor. The location of the facility itself is on the hill, and the labor's workplace is mostly outdoor; therefore, they could get good air circulation.

The existence of the first phenomenon, with the owner reluctance in finding the new hire, has produced another phenomenon. The situation is that the owner did not feel bothered by his current employees. Therefore, a question of why the owner was not showing the urge to find qualified employees was asked, and the following was the answer.

It is because of the distance of the manufacturing facility. Moreover, it is hard to find someone who can be trusted. Since I am not always around in the facility, then I will need someone that could be trusted (Mr. H, male, 59).

In the above interview, the search for employees is limited to those who could be trusted by the owner. Trustworthiness is the priority value in finding an employee. It becomes essential for the reason of the remoteness of the manufacturing facility location, which is the second phenomenon to occur in this case study.

\subsubsection{Phenomenon 3: Machinery breakage that will reduce the productivity}

The third phenomenon mentioned was the machinery breakage. When it occurs, the entire production system will stop, and eventually affects the productivity. The production result will be reduced, and as the consequence, production target and the sales target will not achieve. In the end, the primary goal of the business, the monetary 
profitability, will not be reached. The following is the testimony from the administrator regarding the machinery breakage.

Initially, I was a mechanic in this company. I installed types of machinery and maintained them. I was already here since the establishment of the company. While everyone else has left, I stayed. After the prior administrator resigned, I was assigned to be the new administrator. However, since I was the only one who understood types of machinery, I was still also working as the mechanic. And when it happened, we cannot produce the limestone powder as targeted. At that time, I was scolded by Mr. Y for that (Mr. I, male).

In the interview session, the administrator mentioned that he initially worked as a mechanic in the company. After three years of service in that area, he was promoted to be the administrator, after the latest resigned from the position. The administrator mentioned that after his replacement, the machine often crashed and terminated the entire production process. Therefore, occasionally he helped the current mechanic to repair the machine.

It can be seen from this section that the machine condition was very crucial for this company, remembering the nature of this company is very dependent on its machinery. It is shown from the administrator's story that the manager was angry when the machine broke and the production process could not be continued. To support the Authors opinion on this matter, the following is the statement from the owner, which include his confirmation of the importance of the machine condition.

When the machine broke down, the production flow cannot be continued, so it [the production] is suspended. It is regrettable for us since we cannot sell our product to our customers. If this continues to happen, our profit will go down, and eventually, our customers might be looking for another supplier (Mr. H, male, 59).

Based on the owner's perspective, machinery's usage and maintenance also play an essential role in ensuring the continuity of the company. Concluding from his statement, proper machinery is an excellent investment to secure their prospective customers. Therefore, machinery breakage could also be taken as one of the phenomena occurred. 


\subsubsection{Phenomenon 4: Lack of employee training}

Linked with the prior phenomenon, the Authors was motivated to acquire the machinery maintenance procedure. Other than that, the Authors was aiming to see whether all mechanics involved has acknowledged the procedure or not. Then, the next question to be asked was whether mechanics had been trained to execute the procedure or not. The following is the response from the administrator regarding the machinery maintenance procedure and training.

There is no formal training done by this company. I am the one who teaches the new mechanic on how to maintain and repair the machine. However, I do not show them regularly, just when they need the training (Mr. I, male).

From the interview above, we can identify another occurrence of a phenomenon in this company, which is the lack of employees training. There is no formal training that was regularly conducted. The training was held only when there was a problem occurred.

\subsubsection{Phenomenon 5: Segregation of duties}

The fifth phenomenon discussed is about the uneven distribution of responsibilities. Authors have found evidence that proves inadequacy in segregation of duties through the interview data. From all of the respondents, two of them hold a variety of roles, which generally are owned by different individuals. The following was the manager answer when he was asked about his positions and duties in this company.

I am in charge of controlling the human resources in the factory, as the supervisor, as well as the one who selects employees. I also hold the administration in the company for things that other people must not see, for example, prices and profits. I also responsible for the marketing effort and the sales made. I am the one who finds customers and lobby customers (Mr. Y, male).

It is clear from the manager's statement that in this company, one person holds so many roles and duties at the same time. However, the Authors has found that Mr. Y is not the only one who owns a variety of responsibilities and positions in the business. Therefore, the similar question was also asked the administrator, and the following was his answer. 
Other than being the administrator, I also gave informal training to the new labors that were in charge of the machinery maintenance. However, since I slowly withdraw from my duty as a mechanic, the machines started to be broken. I was not blaming them for that since I also do not have the time to train them regularly (Mr. I, male).

Not only the manager, from the previous section of the interview it can be seen that the administrator also holds several parts in this company; not only as an administrator but as the occasional mechanic as well. Those roles could be said as contradicting to one another and may confuse the executor.

\section{Results and Discussion}

In identifying problems critical thinking and deep understanding of the company, as well as the phenomena, are needed. The following is the graph of the identified problems.

The first two phenomena, an unsatisfactory employee, and location are intimately connected to trustworthiness. This is due to the fact these factors relate to the owner's capacity and control. The following describes these aspects in detail:

Figure 1.

Problem Identification Diagram
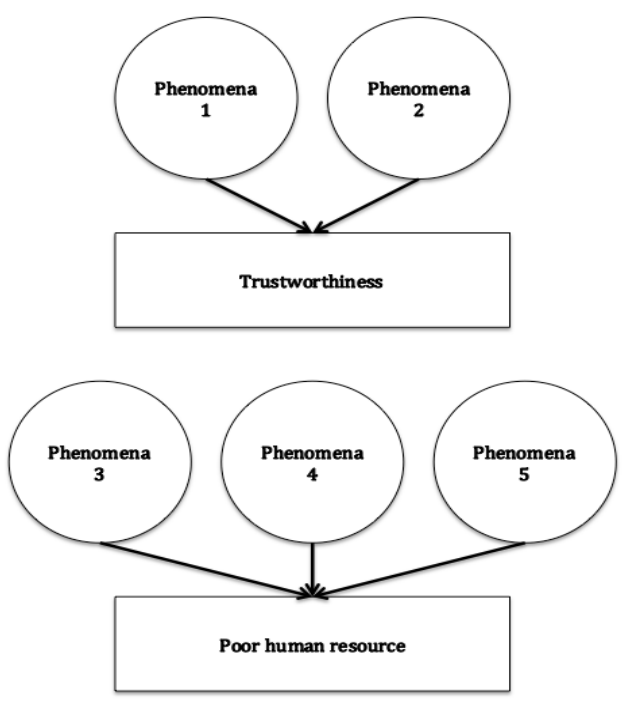


\subsection{Trustworthiness}

Trustworthiness is a common characteristic that mostly found in SME family business, especially in Indonesia (Efferin \& Hopper, 2007; Efferin \& Pontjoharyo, 2006; Wijaya, 2008). This value is crucial to have in businesses; since it assures the stakeholder that they could rely on their mates or even subordinates. The same occurs in PT. GAA, where it identifies the need for trusted employees to run the daily operation in the manufacturing facility. This is in accordance to Efferin and Hartono (2015) finding that a leader is also a manager that is constructed by societal culture. However, there are issues of this value. The need for trusted employees contradicts the qualities of human resource. During the interview, the owner mentioned that his current employees are not satisfactory enough in delivering their services. In a typical organization, the owner attempts to find a new candidate that has better working quality. However, in this company, the Authors did not detect any desperation in terms of searching for qualified employees. This is aligned with Redding (1993), Efferin and Pontjoharyo (2006) and Wijaya (2008) where personal development is less prioritized in a Chinese company due to agitation to spend more money.

Also, the owner was also straightforwardly to utter his needs of trusted people in his business, since it is located in the remote area and the owner cannot present personally in the facility. Hence, this business was built on a foundation of trust, which in line with the Chinese Guanxi (Lin \& Ho, 2010). In this case, the owner prefers to have his relative or other trustable people to operate the business, since the plant site is remotely located. In contrast, allocating quality staff has been his second priority.

Implementing action control could eliminate the possibility of fraud in the company, thus increasing the trustworthiness of employees (Merchant \& Van der Stede, 2007). The need for a trusted person to work in the business is a subjective matter, which cannot be solved using the MCS theory. In providing a solution to an SME like PT. GAA, this paper offers four step resolutions. The first step is to create a favorable environment and to reduce behavioral constraints. A small enterprise must impose control over employee undesirable employee's behavior. According to Merchant and Van der Stede (2007), the implementation of behavioral constraints can be physical or 
administrative. Ideally, all classified documents need to be stored in a secured location and being locked. It is crucial to separate each people duties; therefore, each decision is made by an authoritative person. In practice, PT. GAA has secured all its essential documents but fails to implement full segregation of duties. With the small size of employees and many positions to offer, it is impractical to achieve complete separation of duties. Such implementation of Chinese guanxi within this enterprise must be shifted from centralized management, into a delegation of the job description to a trusted person in the plant site. Efferin and Pontjoharyo (2006) suggest that adequate control is needed by educating self-responsibility to achieve the target.

The second step is a pre-action review, which involves the manager to evaluate the employee's action plan before executed (Efferin \& Hartono, 2015). It applies to be implemented in this company. For instance, when there is an option to increase the stock level or in building a new relationship with new suppliers/customers, it is necessary for the action plan to be reviewed by the superior. In PT. GAA the manager makes the marketing, production, and other crucial decision. Therefore, the control needs to be put upon him, and the owner himself should review the action plan before it is done. Since the informality in this company is high and the location is quite far, thus the pre-action review could be done through telephone communication.

The third step is action accountability, meaning that employees will be held accountable for any action that they did. To make this control efficient, it is essential for the company to provide the knowledge of the desired action. When the employees are aware of the expected response, it will be reasonable to hold them accountable for their work. Afterward, good effort should be rewarded while lousy behavior should be punished. It is also applicable to be implemented in PT. GAA. The fourth step is redundancy, which includes assigning more people to do the same job. However, it is highly unfeasible especially in this company, which does not use a system in operation and employs a small number of employees.

\subsection{Human Resources issue}

Employees are one of the essential elements of a company. However, failure in optimizing human resources function is detected in the business. It is proved by the 
occurrence of the last three phenomena. All of the respondents have mentioned about the machinery breakage; the owner expressed his disappointment on how the machine was not maintained properly, and the administrator (ex-mechanic) was also admitted the loss incurred because of that issue. From the information provided, the machinery was broken because current mechanics did not receive adequate training on how to maintain the machinery. The administrator confessed that he did not have time to provide formal training to his successor. As the consequences, the following mechanic did not have a sufficient ability to maintain and repair the machinery.

Another issue that still relevant to human resource problem is the uneven distribution of duties among the employees. The manager embraces several crucial roles in the company (as the manager, marketer, labor supervisor, high-level administrator, and the human resource department head). Also linked with the first problem, the manager has to handle all of these duties since he is the only person who holds the owner's trust. This argument contradicts Efferin and Pontjoharyo (2006), where the Chinese are concerned with the recruitment and training process. However, this finding supports García Pérez de Lema and Duréndez (2007) that small business tends to have recruitment and training issues. The possible reasoning might be connected to the low willingness to spend extra fund for additional staff development. Hence, this phenomenon opposes the concept of Guanxi where improving one's skill is essential.

\section{Conclusion and Recommendation}

MCS consists of general measures human capital and performance management that can assist an organization in order. The paper analyzes the extent to which MCS enables to identify performance, as well as human resource issues, in conjunction with management control in a small manufacturing company. In a particular setting such as Indonesia, other components, such as cultural context, collectivism, leadership, and ethnic group, contribute into an essential factor in MCS. An enterprise such as PT. GAA illustrates various issues as a small manufacturing business, that closely related to family business and cultural dimensions. It is believed that even a generic MCS has little implication towards its performance improvement. 
Overall, MCS provides an appropriate guideline to improve a company's performance and management control, and budgeting issues. However, most of the literature that scrutinize Indonesian SME found that the socio-economic milieu influence more than the procedural systems designed by the theory. It is proven that cultural aspect, both inside and outside - organization, influences greater than what is advised within the MCS theory. Although some references refer on the extent to which cultural context serves as the fundamental basis to management control in the small enterprises, there is still lack of understanding and technical procedure on how to accommodate such local content. A remaining question to be considered in the future is 'how do you cater Indonesia's domestic culture when handling small businesses?', in which the authors believe to have a misleading association between the Western and Eastern way of doing business. Interdisciplinary fields, containing sociology, anthropology, and psychology enable to scrutinize the need to modify MCS concerning local content. Hence, an appropriate indicator of MCS would be appreciated when observing Indonesia's small enterprises, and likely to accommodate all aspect of a small organization in various places in Indonesia.

\section{Reference}

Anggadwita, G., Luturlean, B. S., Ramadani, V., \& Ratten, V. (2017). Socio-cultural environments and emerging economy entrepreneurship: Women entrepreneurs in Indonesia. Journal of Entrepreneurship in Emerging Economies, 9(1), 85-96.

Berghe, L., \& Carchon, S. (2003). Agency relations within the family business system: An exploratory approach. Corporate Governance: An International Review, 11(3), 171-179.

Berry, A., Rodriguez, E., \& Sandee, H. (2001). Small and medium enterprise dynamics in Indonesia. Bulletin of Indonesian Economic Studies, 37(3), 363-384.

Chenhall, R. H. (2003). Management control systems design within its organizational context: findings from contingency-based research and directions for the future. Accounting, Organizations and Society, 28(2), 127-168.

Creswell, J. W. (2014). Research design: Qualitative, quantitative, and mixed methods approaches (4th ed.): Sage publications. 
Efferin, S., Frisko, D., \& Hartanto, M. (2016). Management control system, leadership, and gender ideology: A study of an Indonesian construction company. Journal of Accounting in Emerging Economies, 6(4), 314-339.

Efferin, S., \& Hartono, M. S. (2015). Management control and leadership styles in family business: An Indonesian case study. Journal of Accounting \& Organizational Change, 11(1), 130-159.

Efferin, S., \& Hopper, T. (2007). Management control, culture, and ethnicity in a Chinese Indonesian company. Accounting, Organizations and Society, 32(3), 223-262.

Efferin, S., \& Pontjoharyo, W. (2006). Chinese Indonesian business in the era of globalization: Ethnicity, culture and the rise of China. Southeast Asia's Chinese Businesses in an Era of Globalization: Coping with the Rise of China, Institute of Southeast Asian Studies, Singapore, 102-160.

García Pérez de Lema, D., \& Duréndez, A. (2007). Managerial behaviour of small and mediumsized family businesses: An empirical study. International Journal of Entrepreneurial Behavior \& Research, 13(3), 151-172.

Herath, S., Herath, A., \& Azeez, A. A. (2006). Family firms and corporate culture: a case study from a Less Developed Country (LDC). International Journal of Management and Enterprise Development, 3(3), 227-243.

Hwang, D. B., Golemon, P. L., Chen, Y., Wang, T.-S., \& Hung, W.-S. (2009). Guanxi and business ethics in Confucian society today: An empirical case study in Taiwan. Journal of Business Ethics, 89(2), 235-250.

Lewis, R. D. (2006). When cultures collide: Leading across cultures (Third ed.). Boston: Nicholas Brealey International.

Lin, L.-H., \& Ho, Y.-L. (2010). Guanxi and OCB: the Chinese cases. Journal of Business Ethics, 96(2), 285-298.

Lukiyanto, K. (2016). Mandor; Model Kepemimpinan Tradisional Jawa pada Proyek Konstruksi Era Modern. Jakarta: Gramedia Pustaka.

Malmi, T., \& Brown, D. A. (2008). Management control systems as a package-Opportunities, challenges and research directions. Management accounting research, 19(4), 287-300.

Merchant, K. A., \& Van der Stede, W. A. (2007). Management control systems: performance measurement, evaluation and incentives: Pearson Education.

Morris, M. W., Leung, K., Ames, D., \& Lickel, B. (1999). Views from inside and outside: Integrating emic and etic insights about culture and justice judgment. Academy of management review, 781-796. 
Mutmainah, S., Prabowo, T., W., \& Raharja, S. (2010). Social Construct of Business Entity's Performance Measurer: A Case Study of SME in Kudus. The Indonesian Journal of Accounting Research, 13(3).

Redding, S. G. (1993). The spirit of Chinese capitalism (Vol. 22): Walter de Gruyter.

Senftlechner, D., \& Hiebl, M. R. (2015). Management accounting and management control in family businesses: Past accomplishments and future opportunities. Journal of Accounting \& Organizational Change, 11(4), 573-606.

Sharma, P. (2004). An overview of the field of family business studies: Current status and directions for the future. Family Business Review, 17(1), 1-36.

Smith, M. (2011). Research methods in accounting: Sage Publications.

Sorenson, R. L. (2000). The contribution of leadership style and practices to family and business success. Family Business Review, 13(3), 183-200.

Tambunan, T. (2005). Promoting small and medium enterprises with a clustering approach: A policy experience from Indonesia. Journal of Small Business Management, 43(2), 138-154.

Tsamenyi, M., Noormansyah, I., \& Uddin, S. (2008). Management controls in family-owned businesses (FOBs): A case study of an Indonesian family-owned University.

Wijaya, Y. (2008). The prospect of familism in the global era: A study on the recent development of the ethnic-Chinese business, with particular attention to the Indonesian context. Journal of Business Ethics, 79(3), 311-317. 
The Indonesian Journal of Accounting Research-May, Vol. 21, No.2 , 2018

intentionally blank 